\title{
Fallopian Tube Cancer pNX TNM Finding v7
}

National Cancer Institute

\section{Source}

National Cancer Institute. Fallopian Tube Cancer pNX TNM Finding v7. NCI Thesaurus. Code $C 89683$.

Fallopian tube cancer in which regional lymph nodes cannot be assessed. (from AJCC 7th Ed.) 